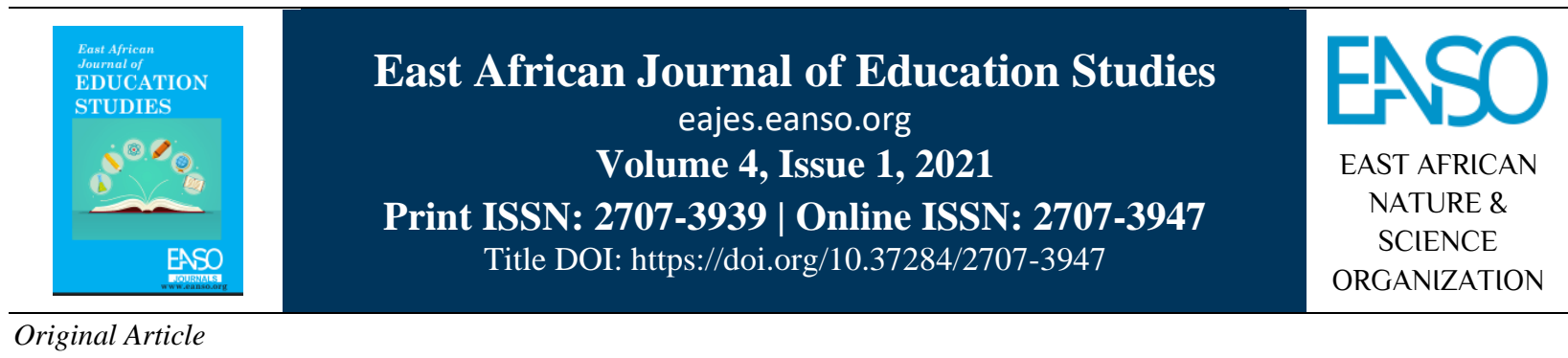

\title{
How Poetry as A Dual Genre Draws its Themes from the Author's Origin, History and Setting: A Case Study of Two Selected Kiswahili Poetry Books.
}

\author{
Dr. Kibigo Mary Lukamika, $P h D^{1}$ \\ ${ }^{1}$ Tom Mboya University College, P. O. Box 199-40300 Homa Bay, Kenya. \\ * Author for Correspondence ORCID ID: https://orcid.org/0000-0001-5454-0123; Email: kibigomary@ gmail.com.
}

Article DOI: https://doi.org/10.37284/eajes.4.1.516

\section{Date Published: ABSTRACT}

21 December 2021 The study explores how poetry as a dual genre draws its themes from the origin, history and setting or environs of the author in the society. Basically, literature like

Keywords: any other art has its own way of expressing its aesthetic value. This is done through the channel of language. On the other hand, literature has many genres. Despite that,

Literature, poetry is considered to be the most ancient genre in many communities universally.

Oral Literature, Poetry, therefore, is a genre that has a dual nature, which implies that it is a genre

Written of both oral and written literature. Kiswahili poetry encompasses itself fully with

Literature, the society in question, its ideologies, philosophies, traditions, culture, and the

Poetry, general life of the Swahili people without taking into consideration the language in

Poems, which it was constructed. Therefore, it is not possible to disassociate the Kiswahili

Dual Genre, poetry from their culture as it is fully drawn from their way of life. Since a people's

Setting, culture is enclosed in their language, this study selected two Kiswahili Poetry books

Culture, through purposive sampling to show how poetry draws its themes from the author's

Origin, origin, history, setting, and culture. The selected books were: Sikate Tamaa (Said

Philosophy, A. Mohamed) and Dhifa (Euphrase Kezilahabi) The study employed the

Ideology, Hermeneutics theory as interpreted by (Newmark and Michael Forster, 2007). This

Tradition, theory was very vital to this study as it puts into consideration the words used, the

Purposive history and culture of the author, context, and specific analysis of the text to come

Sampling, up with the objective of the general text. The study also used textual analysis as well

Hermeneutics as an observation checklist to analyse data. The study discovered that poetry is rich

Theory, and has a lot to be desired as far as teaching and depicting the author's origin,

History. history, and setting in the society is concerned hence drawing the themes from that.

This study aimed at highlighting the need for more in-depth research as this can reduce the negative notion that poetry is a hard and complicated genre to some learners and scholars. There is also a need for the poetry learners to identify the history of the author in order to provide a starting point for the analysis in question.

129| This work is licensed under a Creative Commons Attribution 4.0 International License. 
Therefore, the study proposes that poems be taught at all levels of learning and their various elements in order to enlighten the Kiswahili and English students, scholars, and researchers.

\section{APA CITATION}

Lukamika, K. M. (2021). How Poetry as A Dual Genre Draws its Themes from the Author's Origin, History and Setting: A Case Study of Two Selected Kiswahili Poetry Books. East African Journal of Education Studies, 4(1), 129-137. https://doi.org/10.37284/eajes.4.1.516.

\section{CHICAGO CITATION}

Lukamika, Kibigo Mary. 2021. "How Poetry as A Dual Genre Draws its Themes from the Author's Origin, History and Setting: A Case Study of Two Selected Kiswahili Poetry Books”. East African Journal of Education Studies 4 (1), 129-137. https://doi.org/10.37284/eajes.4.1.516.

\section{HARVARD CITATION}

Lukamika, K. M. (2021) "How Poetry as A Dual Genre Draws its Themes from the Author's Origin, History and Setting: A Case Study of Two Selected Kiswahili Poetry Books”, East African Journal of Education Studies, 4(1), pp. 129-137. doi: 10.37284/eajes.4.1.516.

\section{IEEE CITATION}

K. M. Lukamika, "How Poetry as A Dual Genre Draws its Themes from the Author's Origin, History and Setting: A Case Study of Two Selected Kiswahili Poetry Books", EAJES, vol. 4, no. 1, pp. 129-137, Dec. 2021.

\section{MLA CITATION}

Lukamika, Kibigo Mary. "How Poetry as A Dual Genre Draws its Themes from the Author's Origin, History and Setting: A Case Study of Two Selected Kiswahili Poetry Books". East African Journal of Education Studies, Vol. 4, no. 1, Dec. 2021, pp. 129-137, doi:10.37284/eajes.4.1.516.

\section{INTRODUCTION}

Kiswahili poetry has the longest history due to its function in human society. Most scholars pose this question, 'What is poetry?' This is a question that requires a lot of keenness before coming up with a solid and concrete answer. This is so because varied scholars have defined poetry differently. Some scholars propose that the definition be based on the laid down. Classical rules while others tend to propose that it should be based on themes. Ahmed (2020) asserts that poetry is rooted in the culture of the society in question. Culture encompasses language which is a peoples' identity. Conversely, history is a component that illuminates the future. Therefore, in this context, an author's thematic perspective cannot be separated from his origin, history, setting, and culture. Seemingly, the author does not draw his themes from a vacuum but rather from his origin and history. In essence, this paper has the task of discussing and showing the relationship between literary works; poetry, setting, origin, and the history of the author.

\section{RELATED LITERATURE}

Various studies have been done concerning the meaning of poetry, its origin, and the conflict between the ancient view and the modern view of the genre. The concept of Kiswahili poetry has attracted very many scholars who have come up with very many different definitions. This has made the concept to be complicated in nature. Despite the varied definitions, most researchers agree that the origin of poems was the songs that were sung during the early days of the life of human beings. Maitaria (2017) in support of the views of Mbaabu (1996) states that initially, poetry was constructed based on culture and the Swahili setting but due to the expansion of Kiswahili and its usage, it has spread to East Africa and other countries all over the globe. Wanjala (2011) explains that poetry began as soon as man embraced songs and started using them in his day-to-day activities like fishing, harvesting, planting, and while plaiting or weaving. Wanjala (ibid) explains that this is so because oral literature is the mother of written literature. This is why poetry as a genre has a dualism kind of nature.

Senkoro (2011) suggests that the definitions can be regrouped into two main groups: the ancient and the 
modern view. In essence, poetry uses the language that is shortened and it explains its themes in a summary form. He adds that the themes are normally concealed in imagery and symbolic form. Thus, this is very fundamental when it comes to reading and analysing poems. Indede (2008) states that you can never understand a poem unless you read it with an innermost eye repeatedly. The scholar asserts that it requires in-depth unravelling and keen reading of the poems in order to get the meaning. Therefore, the history of the author or the poet in question is very fundamental.

The proponents of the ancient view include; Abedi (1954), Shaaban Robert (1971, 1972), Mnyampala (1965) and Abdalla (1973) among others. Conversely, some of the propounds of the modern view include; Ebrahim Hussein, Alamin Mazrui, Kithaka wa Mberia, Euphrase Kezilahabi, Fikeni Senkoro, and Kulikoyela Kahigi among others.

\section{The Hermeneutics Theory}

This theory was interpreted by Newmark in 1988. It is referred to as the translated theory of arts. Initially, this theory was strictly used in law and religious works. It was mainly used to interpret the public laws, religious laws, and more so it was used in interpreting religious texts. Most scholars and researchers started using it until it became famous and was now used in analysing texts. The Propounds of this theory include Jacques Derrida, Schleiemacher, Wilhelm Dilthey, Marthia Heidegger, and Haus-Georg Gadamar. The theory continued to take roots in its usage until it was not only used in matters of religion and laws but rather it was able to be used in the analysis of any text. Poetry works in Kiswahili like Sikate Tamaa (Said A. Mohamed) and Dhifa (Euphrase Kezilahabi) can be analysed using this theory. Basically, the Hermeneutics theory is grounded in the understanding of the history of the author. The theory is encompassed on the tenets of history, language, and culture.

Hermeneutics as a theory is very rich because, it does not just take the role of interpreting a language into another but rather it also involves communicating with others using their language and, in this case, the Kiswahili language is used as our primary data. Therefore, based on this logic,
Hermeneutics is a practice of interpreting how meaning can be transferred from the original language to another language, for this case from Kiswahili to English. Hermeneutics as a theory has been evolving and changing shape daily. Its development can be traced from the first step of asking, 'How do we say it?' to 'How can we put it across or how do we present?' These were the discoveries that came up from the propounders like Henry A. Vinkler, Friedrich Schleiermacher, and Wilhelm Dilthey. For instance, Henry A. Vinkler (1981) in his book Hermeneutinus: Principles and Processes of Biblical Interpretation, proposes four tenets that he refers to as the four steps of interpreting meaning. These are; Discovering the words used, the history and culture of the author are important, understanding the context and specific analysis of the text to discover its purpose. In essence, this theory was very vital to this paper as it assisted us in discovering that understanding the author's origin, history, setting, and culture enables a reader to interpret literary works like poems with a lot of ease hence the importance of reflection. Many researchers are embracing this theory as it tackles the day-to-day occurrences in the society that we live in.

Therefore, in this paper, the Hermeneutics theory has been used because it is based on perspectives, expectations, meaning, and philosophy of language. This has enabled the researcher to unravel the history of the two authors to come up with the related themes in their poems.

\section{METHODOLOGY}

This paper used a descriptive research design. The study area was the genre of poetry in Kiswahili literature. The study was done in the library as it involved the analysis of texts and it focused on two authors and their various poems. This was done by employing a purposive sampling technique that states that a researcher is free to sample purposively to research on specific components that could be cutting across on the selected works. Observation checklist and content analysis techniques were used in this study. 


\section{DISCUSSIONS}

A number of poems have been purposely selected for this study. The two authors that were purposively selected were: Sikate Tamaa (Said A. Mohamed) and Dhifa (Euphrase Kezilahabi) Kariuki (2017) explains that literature works can play a big role in depicting the history of the author and also his environment. It is on this logic that this paper discusses how poetry draws its themes from the author's history and setting or rather the surroundings based on the Hermeneutics theory. Therefore, the relationship between the poets in question and their origin, history including the themes drawn have been discussed.

\section{Said Ahmed Mohamed}

Said Ahmed Mohamed was born in 1947 $(12 / 12 / 1947)$ in the islands of Zanzibar. S. A. Mohamed never got an opportunity to be raised by his parents but instead, he was taken care of by his two grandparents namely Rukia and Yohana. He acquired his basic and secondary education from this island. S. A. Mohamed schooled at Weya Boys and joined the school of talented learners called Darajani. He later joined Ukuruma TTC where he graduated as a teacher. He joined the University of Dar es Salaam where he graduated with both a diploma and a degree in Education. He later pursued a Master's degree in Kiswahili linguistics and oral literature in the same University and then he proceeded to Karl Marx Lepzik University in Germany to undertake a Doctorate degree between 1979 and 1985.

In his career as a lecturer, he has taught in the islands of Zanzibar, in the University of Osaka in Japan, and also in Kenyan Universities like the University of Nairobi and Moi. His career as an author of literary works started to take root in the 1960s when he was still young and in primary school. He started off with poetry where he could come up with some poems that were sung and chanted during parents' meetings and sometimes, they were also used in the radio channels of the voice of Zanzibar (Mohamed, 2001). Later on, as a poet, he came up with poems like Sikate Tamaa (1980), Kina cha Maisha (1984), and Jicho la Ndani (2001). He has also involved himself in writing other genres like novels for instance Asali Chungu
(1978) and Utengano (1980) among others. He has also written some short stories including Sadiki Ukipenda na Hadithi Nyingine (2004) and Mfuko Mtupu na Hadithi Nyingine (2005). Among his plays that he has written include Kivuli Kinaishi (1990), Amezidi (1995), and Kitumbua Kimeingia Mchangani (2011). In general, we have tried to look into Said Mohamed's life, his origin, history, and his biography as a writer. This part was very vital as it has helped this paper to put a grounding before embarking on the themes in one of his poetries' books, Sikate Tamaa (1980).

\section{An Example of Sikate Tamaa (Mohamed, 1980)}

According to Mohamed, his first works to be published were those of prose even though he started by writing poems. In most of his works, he appears strongly to be a very firm person ideologically. He values the development of his society and he is fond of putting this into

consideration in nearly all the writings. He values the fact that everybody has a role to play to construct and develop the society. In essence, that is why most of his writings have been dealing with themes like issues of poverty, oppression, the value of women in society, racism, and hypocrisy among others. In this poetry book, we have themes that daw from his origin and the areas he has visited, and also the settings in which Said Mohamed grew in. The writer and in this context the poet were motivated by the praises that he received when he first wrote his poems during his early days in primary school. He was encouraged by his peers and teachers which gave him an impetus to continue with his art of writing. Kezilahabi's poems like Kichomi gave him the vigour and thrill to write poems. This paper explored the following themes: Poverty, oppression, hypocrisy, greed, freedom, laziness, farming, unity, family relationship, and education.

\section{Poverty}

This is the state of being extremely poor. It is also the state of being inferior in quality or insufficient in amount. It may also refer to a situation where one lacks necessities like food, shelter, and clothing. In this poetry book, when we refer to page five, for instance, there is a poem on 'Shairi la Siku Njema' meaning 'A Good Day', the poor people are asking 
for a penny. This means that they have nothing and that is why they are begging for the smallest silver in terms of value 'peni'. Even though, the title of the story is showing that poverty is no longer there because a Good Day- 'Siku Njema' is seen in the morning. When we refer to S.A. Mohamed's history, we tend to discover from his history and setting that he was never taken care of by his own biological parents, he grew up in a state of poverty in the Islands of Zanzibar, a situation that gave him the impetus to write on themes depicting poverty and give hope to the poor.

On the other side, when we refer to a poem on page 3, 'Si Dunia ya Kulala' meaning, 'It is not a World of Slumber' we can tell from this that the poet is reminding us that the Kuala nature of the world that we live in requires us to work hard and avoid laziness in order to curb on cases of poverty in the society. From his history, we discovered that S.A. Mohamed was very hardworking. His hard work and commitment paved the way for him to join a school that was teaching very many talents. This did not just happen in a vacuum but rather he worked for it by writing poems as early as at the primary level. His ladder of education shows that he was not a person who liked sleeping. He Moyo unao timbuko, maudhui tusikiayo

\section{Nayo visa na mauko, manyonge yawakutayo \\ Kwayo sina zuiliko, natoa niyahisiyo \\ Naandika!}

This shows that the author knows the power of a pen and he is able to write as he started writing as early as his primary school days. This motivated him as his poems were read during parents' days and even in radio bulletins. This gave him an impetus for writing more and more, hence the power of the pen. In page 19, there is a poem on 'Sisimizi sisi' where the author is expressing his feelings about the way in which the poor people are oppressed. 'Sisimizi' are small black insects that are ever walked over by people. They have been used by the author to refer to the poor people in society who are looked down upon by the rich. They subject them to all forms of oppression due to the status quo. All these themes including others like hard work as seen on page 8 , commenced on a humble beginning, went to a primary school, then, Secondary, proceeded to the school of talented learners, went to a Teacher Training College, TTC then proceeded to the University to do a diploma, a first degree; undergraduate, second degree; Masters and finally a Doctorate degree. He did not slumber because he continued with the art of writing other genres apart from poetry.

\section{Oppression}

This is a state of being subject to oppressive treatment. It is malicious or unjust treatment or exercise of power, under the guise of governmental authority or opprobrium. In Sikate Tamaa, themes on oppression are expressed in various ways in different poems. For instance, in Page 17, there is a poem on 'Naandika' there is a state of some people who are in power and taking everything for themselves while the subjects are left without anything. The author is showing that the weak have no one to deliver them from the oppression and that is why he is correcting the situation by writing with a pen so that those in power can read and correct. Refer to this second stanza:

My heart is perplexed, the themes we are hearing,

The suffering befalling, the poor and oppressed, I have no otherwise, but to express my feelings

Am writing! (My own interpretation)

there is a poem on 'Nimeona' where the author is showing a case in which a farmer is hardworking and he is throwing or pushing the jembe with a lot of energy in order to succeed and get plenty harvest. This can also refer to the hard work that S. A. Mohamed had throughout his life until he was able to scale very high in life to the level of the professorship. On the same point of hard work, there is a poem in page 1, 'Sikate Tamaa'. Here the author is trying to encourage the youths in the society to work hard and not to give up whatsoever. The poem in the first stanza

says: 
Umeanguka inuka, simama kama mnazi, Umechunika inuka, inuka, tia dawa kwa ujuzi Sasa inuka, inuka, kijana ianze kazi, Sikate tamaa,

In this poem, the author is stressing the fact that the youths need to be empowered and encouraged to work hard as they are tomorrow's leaders. S.A. Mohamed's life was a life of hard work. In his early days, he was brought up by his grandparents and they taught him the importance of working hard always.

\section{Euphrase Kezilahabi (Dhifa, 2008)- The Bounquet}

He was born in 1944 (13-4-1974) in Ukerewe Island in Mwanza, Tanzania. He learnt in a Seminary and he was a brother in the Catholic Church but later he left and married. He received a BA from the University of Dar es Salaam in 1970. He also taught in various schools in his country. He returned to the University to take graduate work and teach in the department of Swahili. He later completed his graduate studies at the University of Wisconsin in the United States. He grew up to be a scholar who was also a novelist and a poet. He wrote his works mainly in Kiswahili. He has written many literary works including his first novel, Rosa Mistika (1971, 1981, and 1988). He was a specialist in literature and Theory. He wrote his first poetry book known as Kichomi (1970) then he wrote Karibu Ndani (1988) and Stray Truths (2015). Some of his novels include: Mzingile, 1991; Nagona, 1990; Dunia Uwanja wa Fujo (2007); Kichwamaji (1974) and Gamba la Nyoka (2006). Apart from his fiction works, he also presented talks on subjects like 'Aesthetic Ambivalence in Modern Swahili' and also 'The Concept of the Hero in African Fiction'.

\section{Tulipoanza safari nilipenda wako mwanya,}

Sasa nayapenda mapengo yenye mwanya mkubwa, Ambao sikuweza kuuziba kwa dhahabu ya matendo, Wakati ule hukuwa na makunyanzi usoni, Na tabasamu yenye vidimbwi ilinitia kichaa, Sasa ukitema mate huishia kifuani,

Lakini uso wako una mistari iliyoandikwa pendo la kweli,
You have fallen, arise, stand like a coconut tree, You despaired, arise, put medicine in expertise, Now arise, arise young man and start working, Do not give up. (My own interpretation)

He died on $9^{\text {th }}$ January 2020 in Dar es Salaam in Tanzania.

\section{An Example of Dhifa, (Kezilahabi, 2008)}

This poetic book comprises of free poems that are not tied to the laws of Classical theories. In these poems, the writer wants the readers to question themselves, critique, think critically and creatively about their conscience, their feelings, their environment, their politics, their country, their world in general, and also their lives. The poet is relating himself to a teacher who is after enlightening the world. His themes are based on various societal issues including bad governance, racism, religion, life, and death. In essence, his philosophy rotates on the philosophy of Dhana ya Maisha meaning, he is asking this question, 'What is the concept of life? Therefore, Dhifa is a poetic book that tries to focus on the whole philosophy of the life of a human being. The themes in this book include;

\section{Love and Marriage}

Love is an intense feeling of affection. It also refers to great interest and pleasure in something. On the other hand, marriage is the legally or the formally recognized union of two people as partners in a personal relationship (historically and in some jurisdictions specifically a union between a man and a woman). In this book, Dhifa, when we refer to page 49 , there is a poem titled 'Uzi' meaning 'Thread'. In the second stanza, the poem states:

While starting the journey I loved the gap in your teeth,

Now I love the big gaps between your teeth,

Which I could not fill due to golden deeds,

That time you did not have wringles,

A dimples' smile drove me crazy,

Nowadays when you spit it ends up on the chest,

Your face is still labelled true love,

(Own interpretation) 
In this poem, the poet is showing us how his love for his lover commenced from the onset of the journey. According to the poet, the love has not been tilted because of old age but rather he can reflect on the good old days and therefore forced to keep the promise. The poet is reminding the marriage partners to be committed to each other under all odds. When we reflect on the life of Kezilahabi, he was a man with a family which he really cherished. $\mathrm{He}$ married after leaving the seminary. He was committed to raising a family. That is why his thematic world rotates on love and marriage. The idea of a 'thread' as a title refers to the connection that is lifelong and it does not require any kind of quitting unless otherwise. Therefore, according to the poet, love and marriage are like threads of life that should be knitted carefully using a needle.

\section{Humour}

In Dhifa, the poet has used this quality in most of his poems. Humour is the quality of being amusing or comic, especially as expressed in literature or speech. It also refers to the quality of being funny. The writer has used humour to motivate his readers to laugh at issues and also laugh at himself/herself, but then, after doing that, to reflect, be motioned, and discover the universe in which he or she lives. This is a quality that brings about a lot of irony in Kezilahabi's poems. It beckons the reader to look at life from two perspectives for instance, positive and negative. On page 40, there is a poem on 'Zimwi' meaning the 'Monster'. The poem states:

\section{Zimwi limemeza watoto wote kijijini, Sasa lenda likitagaa kuelekea ziwani, Wanakijiji wafuatisha nyayo, Wakihesabu matumaini na kupima hatari, Nyumbani wanawake vilio wameanza, Wakikumbuka uchungu walioupata. \\ Zimwi litujualo limetula likatwisha, Mchangani limekunguwaa kivulini, Likiota pa kulisaidia, Nzi watambaa wakinyonya udenda, Watoto ndani wahesabu mali, Wakifikiria pa kutoboa.}

A monster has swallowed all the children in the village, Now it is dragging towards the lake, The villagers are following the footprints, Counting on hopes and evaluating the danger, At homes, the women have started crying, When they remember the pain

A monster that knows us has eaten and finished us. In the sand, it has fallen under the shade, Dreaming of somebody to salvage it, Flies are scattered all over licking saliva, The children within are counting the riches, Thinking of where to break. (Own interpretation).
In this poem, the poet uses a lot of humour when he tells us that a monster has swallowed all the children in the village, the monster could be referring to a deadly disease like HIV/Aids that has infected the children due to their irresponsible sexual behaviour. The writer then tells us that the villagers have taken a step of following it towards the lake, a sign of danger even to the villagers as they are counting on hopes of getting back their children, and on the other hand, they are also sensing danger. The poet is also putting us in a situation to reflect at home the way the women are sobbing when they think of the pain they incurred while bearing those children. Then, in normal circumstances, a monster that knows you is not supposed to harm you, but then, in this poem, verse 2 of stanza 2 shows that despite the monster knowing the children, it has been able to eat and finish them, this brings about a sense of humour to the reader. In most of Kezilahabi's writings, he is known for this humorous quality as he likes keeping the fire of his readers burning. Other poems that depict humour are found on page 31, where there is a poem on 'Dikteta' meaning 'Dictator'. In this poem, the author is using humour to refer to a leader who is a dictator. He is reminding him that he died a long time ago and that the people he oppressed and killed are now reborn and are now living in children who are dancing with joy as they wash in the bad water that he left. In other words, Kezilahabi is using humour to correct leaders as he reminds them that everything is the vanity of vanity. In the second stanza he says:

\section{Madaraka ni ndoto isiyotegemewa, Ni kuvaa kofia juu ya gari wazi, \\ Leadership is a dream that you do not bank on, It is like putting on a cap on an open vehicle,}


Lendalo mbio kuvuka mto wa haki, Ambao daraja lake limechukuliwa, Na mafuriko ya sheria ulizovunja, Ambalo breki zake ni roho za watu, Na matairi yake ni mafuvu manne, Ya wale uliowaita vichwangumu, Haini namba wani wa fikra zako.
Hurrying to cross a river of truth, On which the bridge has been taken, With overflowing rules that you broke, Whereby its brakes are people's souls, And its tyres are four skulls, Of those whom you refered to as hardcores, First hypocrite of your feelings. (Own interpretation)
In this stanza, the poet uses a lot of humorous words when he refers to dictatorship or leadership like a dream that should not be banked on. $\mathrm{He}$ is comparing it to putting on a cap on an open vehicle as seen in verse 2 above. In verse 7, he is telling us that its tyres are four skulls, meaning, the vehicle of a dictator cannot move. All these are ways in which Kezilahabi is using imagery to bring out humour to his readers.

\section{Oppression}

In this poem, 'Shairi kwa walimu wote,' meaning a 'poem to all teachers', on page 1 , the poet is expressing the themes of oppression by showing how teachers do a lot of work but they are only paid peanuts. Kezilahabi is also saying that despite that, the teachers are afraid and they cannot fight for their rights for fear of being sucked. They are too nervous even to say that they are suffering. This is also seen in the life of Kezilahabi, initially, he lived in a seminary but he was also having his own fears but later on, he left and married, these could be some of the reasons why he wants his readers to look at life from two dimensions and salvage themselves from any form of oppression. Actually, he is very versed with life experiences because he has tasted both the inside life of spirituality known as the sacred part and the secular life. From the poet's fiction work and talks on heroes and aesthetics, we can note that he was ever fighting for delivering people from oppression, not only from external oppression but also from internal oppression. This is evident in most of his works including the novels.

\section{CONCLUSIONS}

In this paper, I have discussed how the poetry work of two authors; Said A Mohamed (Sikate Tamaa, 1980) and Euphrase Kezilkahabi (Dhifa, 2008) draw themes from their history, origin, and culture. The history of the authors has helped the researcher to analyse the poems with a lot of ease based on the theory of Hermeneutics. However, there are some reknowned scholars like Walibora Ken who wrote and exceeded their origin by not limiting themselves to their history and origin but they wrote themes relating to other areas like for instance the character known as Kongowea Mswahili in his book, Siku Njema (A Good Day). It is hoped that this work will inspire and put an insight in future researchers, scholars, and literature students.

\section{REFERENCES}

Abdalla, A. (1973). Sauti ya Dhiki. Nairobi. Oxford Universuty Press.

Abedi, K. (1954). Sheria za Kutunga Mashairi na Diwani ya Amri. Nairobi: Kenya Literature Bureau.

Ahmed, A. H (2020). 'Ushairi na Utamaduni' Makala katika jarida la Swahili Studies', Vol.1, 2020 uk. 2-5, Kenya: Chuo Kikuu cha Pwani.

Born, W. (1986). The aesthetic of visual poetry. Chicago: Chicago University Press.

Heidegger, M. (1971). The Origin of the Work of Art. In, Poetry, Language, Thought, by Heidegger, M.

Indede, F. N. (2008). Mabadiliko katika Umbo la Ushairi na Athari zake katika Ushairi wa Kiswahili. Swahili Forum 15: 73-94

Kariuki, G. J. (2017). 'Jinsi Kazi za Fasihi Zinaakisi Historia na Mazingira ya Mtunzi' katika Jarida la Lugha na Fasihi katika Karne ya Ishirini na Moja, uk. 167-185. Eldoret: Chuo Kikuu cha Moi.

Kezilahabi, E. (2008). Dhifa. (Vol. 13). Nairobi: Vide-Muwa Publishers.

Kezilahabi, E. (1973). "Ushairi wa mapokeo na wakati ujao" katika zinduko Na 1, Jarida la 
Chama cha Kiswahili. Dares Salaam: Chuo Kikuu cha Dar es Salaam.

Maitaria, J. N. (2017). Dhima ya ushairi wa Kiswahili katika kuelimishia jamii kuhusu demokrasia. Kiswahili, 77(1).

Mbaabu, I. (1996). Language Policy in East Africa. Nairobi: Education Research and Publication.

Forster, M. N. (2007). Hermeneutics Theory. Retrieved on 1/12/2021, philpapers.org

Mnyampala, M. (1965). Diwani ya Mnyampala. Nairobi: Kenya Literature Bureau.

Mohamed, S. A (1980). Sikate Tamaa. Nairobi: Printing Services Ltd.

Mohamed, S. A. (2002). Jicho la ndani (Vol. 147). Longhorn Publishers. Kenya.

Robert, S. (1971). Mashairi ya Shaaban Robert. Nairobi. Nelson and Sons Ltd.

Robert, S. (1972). Sanaa ya ushairi (Vol. 7). Thomas, Nelson and Sons Ltd.

Senkoro, F. M. K. (2011). Fasihi. Dar es Salaam. Kauttu Limited.

Vinkler, H. (1981). Basic Hermeneutical Principles-Squarespace, retrieved on 2/10/2021, https://static1 squarespace .com

Wanjala, F. S. (2011). Kitovu cha Fasihi Simulizi: Kwa Shule, Vyuo na Ndaki. Mwanza: Serengeti Educational Publishers (T) Ltd. 